\title{
The Role of Investment-Based Islamic Crowdfunding for Halal MSMEs: Evidence from Indonesia
}

\author{
Zaki Abdullah $^{1}$, Akhmad Akbar Susamto ${ }^{2}$
}

\begin{abstract}
Investment-based crowdfunding can serve as an alternative financing tool for Micro, Small and Medium Enterprises (MSMEs) in Indonesia. The development of these services can also boost the progress of halal industry because both have integrated relationships. However, not all funding campaigns for crowdfunding services are successful. This study aims to analyze the development of Islamic crowdfunding business in Indonesia and factors affecting the success of funding campaigns in these services. Primary data obtained through interviews and literature review while secondary data is collected from 39 funding campaigns in 4 Islamic crowdfunding online services. Using a quantitative approach, it finds that funding target, campaign duration, payback periods and rate of return have positive effects on campaign success, while a minimum amount of investment has a negative effect. Finally, SWOT analysis was conducted to find out the challenges and opportunities for the halal industry in utilizing such Islamic crowdfunding service.
\end{abstract}

Keywords: Crowdfunding, Islamic Financial Technology, Halal Industry, Investment

Abstrak. Crowdfunding berbasis investasi dapat menjadi sarana pembiayaan alternatif bagi UMKM di Indonesia. Berkembangnya layanan tersebut turut mendorong kemajuan industri halal karena keduanya memiliki hubungan terintegrasi. Namun, tidak semua kampanye pendanaan pada layanan crowdfunding berhasil. Penelitian ini bertujuan untuk menganalisis perkembangan usaha crowdfunding syariah dan faktor-faktor yang memengaruhi keberhasilan pendanaan pada layanan tersebut. Data primer diperoleh melalui metode wawancara dan kaji literatur sedangkan data sekunder diperoleh melalui 39 kampanye pendanaan pada 4 situs crowdfunding syariah. Target pendanaan, durasi kampanye, jangka waktu pengembalian dan tingkat bagi hasil memiliki pengaruh positif terhadap keberhasilan kampanye, sementara jumlah minimal investasi memiliki pengaruh negatif. Setelah melakukan penelitian dengan pendekatan kualitatif dan kuantitatif, analisis SWOT dilakukan untuk mengetahui tantangan dan peluang bagi industri halal dalam memanfaatkan layanan crowdfunding.

Kata kunci: Urun Dana, Fintech Syariah, Industri Halal, Investasi

\footnotetext{
${ }^{1,2}$ Graduate School University of Gadjah Mada-Indonesia

E-mail: ${ }^{1}$ zaki.abdullah@mail.ugm.ac.id, ${ }^{2}$ akhmad.susamto@ugm.ac.id
} 


\section{Introduction}

Access to capital is a challenge for businesses in the Micro, Small and Medium Entreprises (MSMEs) sector and start-ups. Crowdfunding is an alternative investmentbased financing for MSMEs and start-ups. MSMEs sector accounts for nearly 99.99\% of the total businesses in Indonesia (Kemenkop RI, 2017). In 2017, the number of loans proposed by MSMEs was 942.4 trillion rupiah (Badan Pusat Statistik, 2018). This figure reaches half of Indonesia's National Revenue and Expenditure Budget (APBN).

The Central Bank of Indonesia (2018) stated that Indonesia, as a country with a majority Muslim population, has great potential to expand the market share of its halal industry. One of the strategies to develop such potential is empowering halal MSMEs through financial technology (fin-tech). One of such financial technology services are peer-to-peer lending services to provide cash loans from lenders directly to fund beneficiaries. Through access to direct investment from technology-based communities, it can promote the growth and development of MSMEs.

The Indonesia Islamic Economic Masterplan 2019-2024 launched by the Ministry of National Development Planning (BAPPENAS) recommends that in developing halal products, financing must be derived from Islamic finance to maintain its integrated halal value chain. MSMEs can access sources of funding internaly and externaly. Internal funding sources come from personal savings, family and friends (Wati \& Winarno, 2018). External sources of funding come from bank loans, leasing and venture capital providing larger amounts of fund (Fahmi, 2014). In the digital era, financial digitalization provides many conveniences in conducting transactions. The investment process can also be done through the collection of funds via online sites.

The Government of Indonesia, in this case the Financial Services Authority (OJK), began to pay more attention to this crowdfunding service in 2016 with the issuance of a regulation governing information technology-based lending (peer to peer lending) and in 2018 with the issuance of the regulation on equity crowdfunding services. Peer to peer lending services can also be carried out through the crowdfunding mechanism by various investors in fintech companies. However, the existing regulation has not stipulated comprehensive rules regarding Islamic finance. Based on the background above, there are three objectives of this study, namely: firstly, identifying the development of Islamic crowdfunding in Indonesia; second, analyzing the factors influencing the success rate of funding campaign in investment-based Islamic crowdfunding platform; third, analyzing the challenges and opportunities for halal MSMEs using Islamic crowdfunding platform. 


\section{Literature Review}

\section{Islamic Crowdfunding}

Crowdfunding is one of the investment platform in financial technology. It consists of four elements: payment, financial advisor, aggregator and investor. Initially, crowfunding was a participatory online activity where individuals, institutions, nonprofit organizations or companies propose to other groups of individuals, through flexible communication, to perform a voluntary task and provides benefit each other, using their respective capacities such as expertise, funds, knowledge and experience (Arolas and de-Guevara, 2012).

The fundraising method concept through the crowd is actually not a new phenomenon, but the term crowdfunding was first coined in America in 2003 (Freedman and Nutting, 2015). It is to involve the 'crowd' or the wider community to obtain funds, ideas, feedback and solutions for a business activity (Belleflamme et al., 2014). Beaulieu et al (2015) said that crowdfunding is a new term used to collect money from many people who have different backgrounds to participate in the economy and aims to finance each other based on specific needs and criteria. Thus, crowdfunding is a fundraising technique from the wider community for a project or business by utilizing the internet network. In Table 1, there are several Islamic crowdfunding models.

Table 1. Islamic Crowdfunding Model

\begin{tabular}{llll}
\hline $\begin{array}{c}\text { Financing } \\
\text { for }\end{array}$ & $\begin{array}{c}\text { Crowd } \\
\text { Model }\end{array}$ & \multicolumn{1}{c}{$\begin{array}{c}\text { Potential } \\
\text { Beneficiary }\end{array}$} & \multicolumn{1}{c}{ Contracts } \\
\hline Charity & Donation & Microfinance & Hibah, Qard Hasan \\
\hline \multirow{2}{*}{ Product } & Reward & $\begin{array}{l}\text { Microfinance } \\
\text { Small }\end{array}$ & Sale \\
& & $\begin{array}{l}\text { Entreprises } \\
\text { Startups }\end{array}$ & \\
\hline & Microfinance & Murabahah \\
& Debt & Enall & $\begin{array}{l}\text { Ijarah } \\
\text { Diminishing } \\
\text { Investment }\end{array}$ \\
& & Microfinance & Musharakah \\
& Equity & Startups & Musharahah \\
\hline
\end{tabular}

Source : (Marzban S et al, 2014)

The first model of funding is a donation-based crowdfunding. Its purpose is to collect donation funds for social projects such as building schools in the village, renovating orphanages, helping disasters, paying zakat, endowment fees and so forth. 
People who deposit the funds are called donors, as they do not receive any return on the capital they spend. In Indonesia, there are several platforms that accommodate this donation-based crowdfunding service such as kitabisa.com, wujudkan.com and ayopeduli.com.

The next model of crowdfunding services is reward or product-based funds. The depositor will not get a return on the funds deposited rather get gift or other reward in the form of unique and rare services or rights. The type and amount of the prize depends on the paid up capital. This type of funding is usually used to finance creative industry projects such as start-ups and games and so on. Indiegogo.com and kickstarter.com are some examples of such services.

The last model of crowdfunding services is investment-based. There are two types of investment-based models: loans/financing-based and equity/ownership-based. In this service, capital depositors are referred as investors, because they will get the return or profit sharing promised by those who apply for funding campaign through the crowdfunding platform within a certain period. The minimum investment amount has various levels, starting from IDR 50,000 up to IDR 1,000,000 with different levels of risk and return. Dewi (2018) showed that people in Indonesia have a high intention to invest in fintech peer to peer lending. In Indonesia, a few Islamic crowdfunding platforms have official permits from the Financial Services Authority (OJK). The difference between Islamic and conventional crowdfunding services lies in the contract used, the contract in the transaction that takes place in the Islamic crowdfunding service is overseen by the Sharia Supervisory Board (DPS) of the MUI to ensure that there is no element of maysir (speculation), gharar (uncertainty) and riba (usury). In addition, partners who are owned by Islamic crowdfunding business services are Islamic Cooperatives and Baitul Mal in certain areas, so that the elements of supervision and assistance are also carried out in accordance with sharia provisions.

Currently, investment-based crowdfunding services are still dominated by services that provide financing compared to share ownership. When compared with other crowdfunding models, the type of equity-based crowdfunding is a new phenomenon. Each country has different regulations regarding this type of fund collection service (Lukkarinen et al, 2016). This sort of equity-based fund is also often referred as a Mini-Initial Public Offering (IPO) (Freedman \& Nutting, 2015). In Indonesia, the government has just released regulations regarding the equity-based crowdfunding service in December 2018. Although the crowdfunding service has succeeded in collecting quite a large amount of funds, this investment-based fundraising model is new, so research on the topic, especially in investment-based 
crowdfunding services, is quite rare. The regulatory body governing the crowdfunding services using the investment-based model is the OJK (Otoritas Jasa Keuangan/Financial Services Authority as stipulated in Law Number 21 of 2011 concerning the Financial Services Authority. Whereas the type of donation and reward-based funds is regulated under the Law Number 9 of 1961 concerning the Collection of Money or Goods.

\section{Halal MSMEs}

Apriliani (2019) argues that the understanding of MSME owners on financing using the crowdfunding services is still low. Most of them only know the term of lending with certain interest rate so they are afraid of not being able to pay in installments. There are several factors influencing MSMEs to borrow funds through peer-to-peer platforms such as to develop businesses, see affordable loan interest rates, fast and easy loan processes and the need for funds. Other variables such as behavior patterns, income levels of business owners, prestige and habit also influence MSMEs to take loans through peer to peer lending services (Murdwiyanto, 2018).

Building a halal industry needs an integrated shariah-compliant system starting from the financing, regulation, technology development and research stages. The financing aspect is one of the catalysts for MSMEs to develop their business while obtaining halal certification. The crowdfunding service adds an alternative for MSMEs besides borrowing from the banking sector to finance the development of their businesses, especially for micro businesses. Microbusinesses have the smallest percentage in obtaining credit. This is due to the high risk of financing as well as the less promising rate of return considering that micro businesses are not bank-able (BPS 2018).

\section{Methods}

This study uses qualitative and quantitative approaches. Primary data were collected by interviewing Islamic fintech companies staff and reviewing literature on sharia crowdfunding. Secondary data were collected from 39 campaigns from 4 crowdfunding sites that conduct sharia funding for MSMEs namely Ammana.id, Danasyariah.id, Investree.id and Gandengtangan.co.id, all of which are official registered finteches and under the supervision of OJK. Then the data obtained were analyzed using multiple linear regression methods. The model of quantitative approach is as follows: 


$$
\operatorname{Ln} Y_{i}=\beta_{0}+\operatorname{Ln} \beta_{1} X_{1}+\operatorname{Ln} \beta_{2} X_{2}+\operatorname{Ln} \beta_{3} X_{3}+\operatorname{Ln} \beta_{4} X_{4}+\operatorname{Ln} \beta_{5} X_{5}+e_{i}
$$

$\mathrm{Yi}=$ Success rate of Islamic crowdfunding campaigns (\%)

$$
\begin{array}{ll}
\mathrm{B} 0=\text { Intercept } & \mathrm{X} 1=\text { Funding target of MSMEs project (\%) } \\
\mathrm{X} 2=\text { Campaign duration (\%) } & \mathrm{X} 3=\text { Minimal amount of investment }(\%) \\
\mathrm{X} 4=\text { Payback periods }(\%) & \mathrm{X} 5=\text { Rate of return (\%) } \\
\text { ei }=\text { Error } & \text { Ln= Natural Logarithm }
\end{array}
$$

The quantitative approach is carried out to find out what factors influence the success rate of an Islamic funding campaign on the crowdfunding service websites. A series of classical assumptions tests such as normality test, heteroscedasticity test and multicollinearity test were carried out before the F-Statistics test and regression analysis. So the research model is obtained using the double-log method to meet the classical assumption test requirements. After knowing the results of the qualitative and quantitative analysis, a mapping was conducted on the strategy for halal MSMEs to optimally utilize the potential of digitalization of Islamic finance through descriptive analysis using the SWOT (Strengths-Weaknesses-Opportunities-Threats) method. SWOT is a strategic planning method used to evaluate the project of a business.

\section{Results and Discussion}

\section{Islamic Crowdfunding in Indonesia}

In Indonesia, the crowdfunding campaign to fund certain projects in many ways is quite common. For example in 2009 there was a "Coin for Prita" in the case of the Corruption Eradication Commission (KPK). With the development of technology, the phenomenon of financial digitalization ensued, the concept of donations was raised to the online sites of each social institution. But social institutions prefer to collaborate with experts who have a fundraising service platform to raise funds. For example, the National Amil Zakat Agency (BAZNAS) collaborates with the Kitabisa.com platform to collect zakat funds. Then some individuals or religious institutions raise endowments through the crowdfunding service websites. Starting from simply collecting funds for social activities, the idea has been developed into the crowdfunding site to be used for business facilities.

Until October 2019, there were 13 types of fintech businesses that use sharia principles from 144 official fintech lending companies registered in OJK that provide crowdfunding services for investment. However, Ammana.id and Danasyariah.id also provide fundraising services for social projects such as zakat, infaq and waqf. The other fintech financing companies run the conventional business type, however, they provide special fund-raising services for sharia financing, such as Gandengtangan.co.id. 
Table 2. Registered Islamic Crowdfunding Platform in Indonesia

\begin{tabular}{cccc}
\hline No & Name & Website & Year Registered \\
\hline 1 & Investree & investree.id & 2017 \\
2 & Ammana & ammana.id & 2017 \\
3 & Danasyariah & danasyariah.id & 2018 \\
4 & Danakoo & danakoo.id & 2019 \\
5 & Alamisharia & p2p.alamisharia.co.id & 2019 \\
6 & Syarfi & syarfi.id & 2019 \\
7 & Duhasyariah & duhasyariah.com & 2019 \\
8 & Qazwa.id & qazwa.id & 2019 \\
9 & Bsalam & bsalam.id & 2019 \\
10 & Ethis & ethis.co.id & 2019 \\
11 & Kapitalboost & kapitalboost.co.id & 2019 \\
12 & Papitupisyariah & papitupisyariah.com & 2019 \\
13 & Finteksyariah & finteksyariah.co.id & 2019 \\
\hline
\end{tabular}

Source: Financial Services Authority (October 2019)

There are only 13 fintech companies registered as sharia-based ones, however, there are other companies that run Islamic crowdfunding business, even though it has not been officially registered and supervised by OJK such as Indves.com. The legal basis governing the regulation of peer to peer lending sites is found in the Regulation of Financial Services Authority (POJK) No. 77 of 2016 concerning Information Technology-Based Money Lending and Borrowing Services. However, there has been not yet any specific regulation that governs the Sharia-based investment crowdfunding. In fact, such sharia-based financing urgently need the detail rules regarding fund services in accordance with sharia, such as the requirement for DPS in fund collection services, sharia compliance principles, contract mechanisms, Standard Operating Procedures (SOPs).

The regulation regarding equity-based crowdfunding is stipulated in POJK No. 37 of 2018 concerning equity-based crowdfunding through information and technology services. Similar to the regulation governing peer to peer lending, this regulation does not yet regulate Islamic stock offering and the criteria of companies eligible to be included in the stock offering list. Of course this needs to be resolved immediately in order to open up markets for people interested in Islamic finance. There is still 'only' one fintech company that provide this equity-based financial service namely Santara.id.

In such a legal vacuum, MUI issued Fatwa No.117 of 2018 concerning Information Technology-Based Financing Services Based on Sharia Principles. It stipulates that the implementation of fintech must not conflict with the sharia principles such as the contracts or goods or services must avoid elements of maysir, 
gharar, riba, and haram. The contract used in Islamic fintech according to this fatwa is also in line with the musyarakah and mudharabah contracts in funding to business actors. This regulation is intended to develop Islamic fintech in Indonesia. Therefore, fintech businesses wishing to apply for a permission for financing using Islamic crowdfunding mechanism must go through the OJK, and then apply for MUI certification.

The equity-based crowdfunding service can also be used to fund start-ups, such as Santara.id that provides such kind of service. However, there has been none of the start-ups that have offered shares through the official Islamic crowdfunding site, and there is not even a startup that proposes for such Islamic financing. Start-ups in Indonesia still propose financing to conventional fintech.

The procedure for applying for funding to crowdfunding service site is quite easy. It only requires guarantees given by service partners, followed by due diligence and campaign processes. However, the outreach of the service is still quite limited. Gandengtangan.co.id only reaches Jakarta, Bogor, Depok, Tangerang and Bekasi (Jabodetabek), Ammana.id has not yet reached all of Java and Danasyariah.id has a smaller number of campaigns in the site than other sites (always less than 5 campaigns).

In the funding submission procedure, the first thing to do by MSMEs is to contact the crowdfunding service. Second, the crowdfunding service asks its regional partners to conduct surveys and due diligence. Third, a field survey and assessment will be conducted by the partners on the MSMEs. The partners here are the Islamic Cooperatives or Baitul Mal. If the MSMEs are deemed unfeasible by partners, the campaign process is postponed until the business meets the eligibility requirements. However, if it is deemed feasible, the funding campaign process through the crowdfunding service site will begin.

The average businesses funding proposal is USD 210 to USD 350 for the MSMEs in service and trade sectors. While, for the property sector, the amount of funding proposed for the crowdfunding campaign reached USD 34,700 up to USD 70,000 . Funding campaign are conducted from 2 to 30 days. If the funding target has not been reached, a re-bidding can be done up to a maximum of 3 times. However, not all funding was successful. After 3 offers have been made and have not been fulfilled, a discussion is held between lenders and business owners with the crowdfunding service as an intermediary whether they want to continue the financing or not. Based on observations from 39 campaigns that took place in the last period of funding duration, the following are the success rates of the sharia funding campaign: 
Table 3. Success Rate of Observed Funding Campigns

\begin{tabular}{ccc}
\hline No & Success Rate of Crowdfunding & Number of Campaigns \\
\hline 1 & $0-20 \%$ & 13 \\
2 & $21-40 \%$ & 8 \\
3 & $41-60 \%$ & 9 \\
4 & $61-80 \%$ & 6 \\
5 & $81-100 \%$ & 3 \\
\hline & Total & 39 \\
\hline
\end{tabular}

Source : Computed by Authors (2019)

The object being observed is a funding campaign that originates from a $0 \%$ success rate that is just starting to air with a certain duration. Then the success rate was assessed on the last day of the campaign. To overcome the low level of success, a rebroadcast was carried out on the site to collect funds to a maximum of 3 times. Within a small funding target, funding success tends to be faster.

Although crowdfunding methods are popular, the data shows that $81 \%$ of total funding campaigns only reach the target of $20 \%$ of total funding (Forbes dan Schaefer 2017). It means the campaign has not been successful and must be re-aired or withdrawn. If the campaign already aired for 3 times and the funding target has not been fulfilled, the partner owned by fintech sharia can provide the shortfall of fund, because the partner is also an Islamic finance institution.

Based on the observation, the average Return on Investment (ROI) of the investment-based crowdfunding is higher than ROI offered by Islamic Commercial Bank (BUS) or Islamic Rural Bank (BPRS). It reaches $12-16 \%$ p.a. for property projects and around 10-12\% for MSMEs. In 2018, the average equivalent rate provided by BUS and UUS is only 5-6\% per year, while BPRS is 9-12\% per year. Furthermore, Islamic crowdfunding services provide very clear information about investments made by investors compared to depositing funds in banks or buying shares. The crowdfunding site displays its business description, the business owner, the use of financing, the profit sharing estimates, the contracts used and the partners from the MSMEs.

In 2019, the role of Islamic crowdfunding in empowering MSMEs is recorded to have a success rate of funding of up to $96 \%$ with a total investor of more than 100,000 people and total funding disbursed more than USD 10,500,000. The role of Islamic crowdfunding helps more than 6000 MSMEs in Indonesia. With such potential, Islamic crowdfunding still has a market to develop and assist existing MSMEs. Moreover, recently there are 'only' 13 Islamic fintech companies which provides crowdfunding services, a small number compared to conventional fintech companies. 


\section{Success Factors of Funding Campaign}

The success of the MSMEs funding campaign is influenced by several factors. In this study, 5 (five) variables were used to measure the success of the funding campaign carried out on the sharia fintech company website, namely the target of MSMEs project funding, duration of the funding campaign, minimum amount of investment, payback period and rate of return. After conducting a classic assumption test and ensuring that data is normally distributed and there is no multicollinearity and heteroscedasticity, the F-statistics using the Analysis of Variance (ANOVA) table and a regression test is performed. F-statistics results 16.405 and a probability value of 0.000 , therefore it can be concluded that the funding target variable, duration of the funding campaign, minimum amount of investment, payback period and the rate of return simultaneously influence the success rate of MSME funding. Thus, a regression analysis is performed to determine the effect of each independent variable on the dependent variable. But before the regression analysis is carried out, the model is evaluated first by looking at the R-Square value on the results of data processing. After obtaining R-Square value of 0.713 , that can be concluded that $71.3 \%$ diversity of the level of success of sharia MSME funding campaigns can be explained by funding target, campaign duration, minimum amount of investment, payback period and rate of return. Other influential factors of $28.7 \%$ are explained by other variables outside the model.

Table 4. Factors Affecting The Success Rate of MSME Funding Campaigns

\begin{tabular}{lcc}
\hline \multicolumn{1}{c}{ Variables } & Coefficient & Probability \\
\hline Constant & 2.493 & 0.030 \\
Ln Funding Target (X1) & 0.316 & $0.020^{*}$ \\
Ln Campaign Duration (X2) & 0.022 & 0.287 \\
Ln Minimum Amount of Investment (X3) & -0.687 & $0.003^{*}$ \\
Ln Payback Period (X4) & 0.086 & 0.056 \\
Ln Rate of Return (X5) & 1.409 & $0.000^{* *}$ \\
\hline R-Square & \multicolumn{2}{c}{0.713} \\
Prob (F-Statistics) & \multicolumn{2}{c}{0.000} \\
\hline
\end{tabular}

Notes: ${ }^{*}$ ) significant at $5 \%$ level, ${ }^{* *}$ ) significant at $1 \%$ level

Based on Table 4, it is known that there are three independent variables that have a significant effect at $5 \%$ level on the success of the MSME funding campaigns, namely the funding target, minimum amount of investment and rate of return. The other variables have a significant effect at above $5 \%$ level of significance. The funding target variable has a positive effect on the success of the funding campaign, meaning that any increase in funding target of $1 \%$ will increase the success of the funding campaign by $0.316 \%$, ceteris paribus. This figure shows that the low funding target also tends to provide low returns for investors, so the campaign is less attractive to 
fund if the target is too small. If the funding target is increased to a certain number, the financing provided will be spent more on assets in large quantities by business actors, so that the projected profit sharing rate will also go up. This was also proven by the analysis of the correlation between funding targets with the rate of return that shows a correlation number of 0.614 and significant at $1 \%$ level. A high funding target is followed by a high level of profit sharing occurring in the investment fundbased campaign.

The duration of the funding campaign has a positive effect on the level of funding success, that means any increase in funding duration by $1 \%$ will increase the success rate of the funding campaign by $0.022 \%$, ceteris paribus. Not surprisingly, the long campaign duration will provide greater opportunities for projects that apply for funding to be funded by the community. This is consistent with the results of the interview where the duration of the funding campaign can be extended up to 3 times if the project has not been $100 \%$ funded.

The next variable is the minimum amount of investment. It is the only variable that has a negative influence on the success of the MSME funding campaign. Based on the regression results, it can be concluded that each increase in the minimum investment amount by $1 \%$ will reduce the success rate of funding by $0.687 \%$, ceteris paribus. The minimum investment amount for MSMEs in Islamic crowdfunding services is currently IDR 50,000 for micro businesses and IDR 1,000,000 for property business. This means that the minimum investment figure is appropriately determined by Islamic fintech companies, because if it is raised it will reduce the interest of the public to invest because the figure per unit of investment is too large.

On the payback period, the variable has a positive effect on the success rate of funding campaign. Based on the regression results, it can be concluded that each increase in the financing period of $1 \%$ will increase the success of the funding campaign at MSME by $0.086 \%$, ceteris paribus. This figure shows that the characteristics of investors in sharia crowdfunding services want to make long-term investments since the investors aim to maintain the value of their money, besides that they also do not need cash in the short term.

The last variable is the rate of return. It has a positive and significant effect at $1 \%$ level. Based on the results of the regression analysis, it can be concluded that each increase in the rate of return by $1 \%$ will increase the success rate of funding campaigns by $1.409 \%$, ceteris paribus. This is very reasonable, because investmentbased crowdfunding are aimed at making a profit. The higher rate of return offered in a funding campaign, public will be more attracted to invest in the business through crowdfunding service compared to investing in other instruments or simply saving the funds. 


\section{Strategy for Halal MSMEs}

Based on the results of the previous discussion, SWOT mapping was carried out to design an integrated development strategy between crowdfunding-based Islamic fintech and halal MSMEs. Table 5 shows the results of the SWOT analysis.

Table 5. SWOT Analysis of Islamic Crowdfunding

\begin{tabular}{|c|c|}
\hline Strengths & Weaknesses \\
\hline $\begin{array}{l}\text { 1. High Risk-High Return } \\
\text { 2. Investor satisfaction in choosing suitable } \\
\text { investment goal } \\
\text { 3. Easiness of invesment with affordable } \\
\text { minimum amount of investment } \\
\text { 4. Integrated with the development of halal } \\
\text { industry }\end{array}$ & $\begin{array}{l}\text { 1. Not yet well-known by communities } \\
\text { compared to banking sectors } \\
\text { 2. Business project become less flexible } \\
\text { 3. Limited number of Islamic fintech } \\
\text { 4. Limited human resources in digital } \\
\text { marketing and big data management } \\
\text { 5. Limited partners and areas }\end{array}$ \\
\hline Opportunities & Threats \\
\hline $\begin{array}{l}\text { 1. Easiness of fund obtaining for halal } \\
\text { MSMEs } \\
\text { 2. The campaign is not only for funding } \\
\text { but also marketing tools } \\
\text { 3. Open new employment } \\
\text { 4. Muslim as majority population in } \\
\text { Indonesia } \\
\text { 5. Increasing number of internet users }\end{array}$ & $\begin{array}{l}\text { 1. Risk of business failure } \\
\text { 2. The fraud possibility in the funding } \\
\text { campaign of project } \\
\text { 3. Many of Islamic fintech companies } \\
\text { have not been registered } \\
\text { 4. Islamic fintech regulation are separated } \\
\text { from OJK and MUI }\end{array}$ \\
\hline
\end{tabular}

The high number of internet users does not always mean positive, but this is the potential for the financial technology industries to grow continously. At the same time, the number of Islamic fintech companies in Indonesia continues to increase, this is because the majority of the population in Indonesia are Muslim, Islamic fintech platforms are considered as potential. However, in terms of quantity it is not enough, fintech companies must also have good quality because it will provide a mutually beneficial ecosystem between halal industry players, namely between the financial sector and MSMEs. Both have close links to realize an integrated halal industry.

In addition, according to Rusydiana (2018) one of the core problems of the development of the Islamic financial technology industry is the lack of availability of Human Resources (HR), especially HR in the field of digital marketing and big data management. Therefore it is necessary to improve education and the quality of integrated HR between educational institutions, government and industry that focus on this field. It also needs regulations that strengthen the existence of Islamic fintech companies. The existence of Islamic fintech will also improve the quality of halal MSMEs because it is impossible for Islamic fintechs to provide a fundraising 
campaign for non-halal MSMEs if it is well regulated in its regulations. Sudaryanto et al (2013) revealed that difficult access to credit for MSMEs is the biggest problem for the development of MSMEs. Islamic crowdfunding can be a solution to that problem.

\section{Conclusion}

Islamic fintech companies that provide crowdfunding services are still small in number compared to conventional fintech, even though Islamic fintech have great potential in Indonesia with its since Muslim majority population. Crowdfunding services provided by the Islamic fintech companies can increase the capacity of MSMEs through direct financing carried out by the public. The public can directly choose which business fields to invest in with affordable cost and higher rate of return compared to the banking sector. The crowdfunding services from Islamic fintech can collaborates with their partners in the region to reduce fraud and risk of business failure. However, not all funding campaign has been successful. Funding target, campaign duration, payback periods and rate of return have a positive effect on campaign success. The minimum amount of investment has a negative effect, meaning that the minimum amount of investment contained in the Islamic crowdfunding service is already appropriate.

The potential of the development of Islamic fintech can be seen from the increasing number of internet users in Indonesia, so that this can encourage the progress of the halal industry in Indonesia since Islamic fintech and the halal industry has an integrated relationship. In addition to being an alternative financing facility for the halal industry, Islamic fintech can also be a digital marketing tool for halal MSMEs.

\section{References}

Apriliani Rahmawati, Anju Ayunda \& Sarrah Fitriani Fathurochman. 2019. "Kesadaran dan Persepsi Usaha Mikro dan Kecil terhadap Crowdfunding Syariah". Amwaluna: Jurnal Ekonomi dan Keuangan Syariah 3(2).

Badan Perencanaan Pembangunan Nasional. 2018. Masterplan Ekonomi Syariah Indonesia 2019-2024. Desember. BAPPENAS: Jakarta.

Badan Pusat Statistik. 2018. Perkembangan Baki Debet Kredit Usaha Mikro, Usaha Kecil, dan Usaha Menengah (UMKM) Perbankan. Oktober. BPS: Jakarta.

Bank Indonesia. 2018. Indonesia Halal Economy and Strategy Roadmap 2018/19. November. BI: Jakarta.

Bank Indonesia. 2018. Statistik Kredit UMKM Bulan September Tahun 2018. BI: Jakarta. 
Beaulieu Tanya, Sarmily Sarker \& Saonee Sarker. 2015. "A Conceptual Framework for Understanding Crowdfunding". Communications of the Association for Information Systems 37(1): 1-31.

Belleflamme Paul, Thomas Lambert \& Armin Schwienbacher. 2014. "Crowdfunding: Tapping the Right Crowd." Journal of Business Venturing, 29: 585-609.

Estellés-Arolas Enrique \& Fernando González-Ladrón-de-Guevara. 2012. "Towards an Integrated Crowdsourcing Definition". Journal of Information Science 38(2): 189-200.

Fahmi, Irham. 2014. Bank dan Lembaga Keuangan Lainnya: Teori dan Aplikasi. Bandung: Penerbit Alfabeta.

Forbes, Hannah \& Dirk Schaefer. 2017. "Guidelines for Successful Crowdfunding". Procedia CIRP, 60: 398-403.

Freedman David M \& Mathew R Nutting. 2015. "A Brief History of Crowdfunding Including Rewards, Donation, Debt, and Equity Platforms in the USA." Working Paper.

Kementerian Koperasi dan Usaha Kecil dan Menengah. 2017. Perkembangan Data Usaha Mikro, Kecil, Menengah (UMKM) dan Besar (UB) Tahun 2016-2017. Depkop: Jakarta.

Lukkarinen, Anna, Jeffrey E Teich, Hannele Wallenius \& Jyrki Wallenius. 2016. "Success Drivers of Online Equity Crowdfunding Campaigns". Decision Support Systems, 87: 26-38.

Marzban Shehab, Mehmet Asutay \& Adel Boseli. 2014. Shariah-compliant Crowd Funding: An Efficient Framework for Entrepreneurship Development in Islamic Countries. Presented at Harvard Islamic Finance Forum. Boston: USA.

Murdwiyanto, Embun Fathia. 2018. "Faktor-faktor yang Memengaruhi Keputusan UMKM dalam Mengambil Pinjaman Melalui Peer to Peer (P2P) Lending". Bogor. Institut Pertanian Bogor.

Pujiyono, Arif, Ro'fah Setyowati \& Idris. 2018. "Strategi Pengembangan UMKM Halal di Jawa Tengah dalam Menghadapi Persaingan Global". Indonesian Journal of Halal.

Rusydiana, Aam Slamet. 2018. "Bagaimana Mengembangkan Industri Fintech Syariah di Indonesia? Pendekatan Interpretive Structural Model (ISM). Jurnal Al-Muzara'ah 6(2): 117-128.

Sudaryanto, Ragimun \& Rahma Rina Wijayanti. 2013. Strategi Pemberdayaan UMKM Menghadapi Pasar Bebas ASEAN. Pusat Kebijakan Ekonomi Makro. Badan Kebijakan Fiskal. Jakarta: Kementerian Keuangan Republik Indonesia.

Wati, Cicik Retno \& Agung Winarno. 2018. "The Performance of Crowdfunding Model as an Alternative Funding Source for Micro, Small, and Medium-Scale Businesses in Various Countries". KnE Social Sciences: 16-33. 